\title{
REKONSTRUKSI PERJANJIAN KERJA BERSAMA DALAM UNDANG-UNDANG NOMOR 13 TAHUN 2003 TENT ANG KETENAGAKERJAAN
}

\author{
I Dewa Gede Oka Nuryawan (1) , Ida Ayu Sadnyini (2) \\ blideoka@gmail.com ${ }^{(1)}$,iasadnyini@undiknas.ac.id ${ }^{(2)}$
}

\section{Undiknas Graduate School}

\begin{abstract}
This research raises the problem of legal vacuum in Act No. 13 of 2003 which correlates with the absence of regulation in CLA legal force. The formulation of the problem is: How to reconstruct CLA in Act No. 13 of 2003 so as to provide legal assurance in industrial relations?. The purpose and usefulness of the research is to know and examine the issues raised. The legal theory used is the theory of legal ideals, the theory of the level of norms, the theory of justice, and the theory of legal protection. This type of legal thesis research is normative legal research. This normative legal research uses legal approaches, concept approaches and analytical approaches. The result of this research is CLA reconstruction to guarantee legal aspect giving legal certainty aspect through reconstruction of CLA legal force in Act No.13 of 2003. CLA provides aspects of justice in industrial relations by always putting forward justice both in terms of welfare and comfort of work for those who have a weak position in industrial relations. CLA provides aspects of benefit where CLA provides protection of prevention and protection of refresif. Suggestion proposed is the formators of the Act revise the Act No. 13 of 2003 by formulating the force of CLA within. For Industrial Relations stakeholders, CLA can be implemented with a genuine commitment so that the guarantee of certainty, justice and legal protection of workers can be realized in the implementation reality.
\end{abstract}

Keywords: Reconstruction, Collaboration Labour Agreement.

\section{ABSTRAK}

Penelitian ini mengangkat masalah kekosongan hukum dalam UU No. 13 tahun 2003 yang berkorelasi dengan ketiadaan pengaturan kekuatan hukum PKB. Rumusan permasalahan yaitu : Bagaimana rekonstruksi PKB dalam UU No. 13 tahun 2003 sehingga dapat memberikan jaminan cita hukum dalam hubungan industrial ?. Teori hukum yang digunakan adalah teori Cita Hukum, teori Jenjang Norma, teori Keadilan, dan teori Perlindungan Hukum. Jenis penelitian hukum tesis ini bersifat penelitian hukum normatif. Penelitian hukum normatif ini menggunakan pendekatan perundang-undangan, pendekatan konsep dan pendekatan analisis. Hasil penelitian adalah rekonstruksi PKB menjamin cita hukum yang memberikan aspek kepastian hukum melalui rekonstruksi kekuatan hukum PKB dalam UU No.13 Tahun 2003. PKB memberikan aspek keadilan dalam hubungan industrial dengan selalu mengedepankan keadilan baik itu dari sisi kesejahteraan dan kenyamanan kerja bagi pihak yang memiliki posisi lemah dalam hubungan industrial. PKB memberikan aspek kemanfaatan dimana PKB memberikan jaminan perlindungan preventif maupun perlindungan refresif. Saran-saran yang diajukan adalah para pembentuk UU agar merevisi UU dengan merumuskan kekuatan Hukum PKB dalam UU No. 13 Tahun 2003. Untuk para pemangku kepentingan Hubungan Industrial, PKB dapat diimplementasikan dengan 
komitmen yang sungguh-sungguh sehingga jaminan kepastian, keadilan dan perlindungan hukum pekerja dapat terwujud dalam realitas implementatif.

Kata Kunci: Rekonstruksi, Perjanjian Kerja Bersama.

\section{PENDAHULUAN}

Salah satu permasalahan penting pada hubungan industrial dan manajemen sumber daya manusia dalam sistem ketenagakerjaan adalah mengenai hubungan kerja antara pengusaha dengan pekerja atau pengusaha dengan serikat pekerja. Permasalahan ini tidak saja terjadi di Indonesia, namun juga di negara-negara lain di dunia, baik dalam aspek konseptual maupun praktikal. Isu hubungan kerja antara pengusaha dan pekerja atau serikat pekerja berpotensi kuat mengalami penyimpangan. Letak utama penyimpangan umumnya terdapat pada hal-hal pokok seperti pada pekerjaan, upah, sarana, dan iklim kerja yang melingkupinya. Lazimnya pekerja sebagai pihak yang mempunyai daya tawar lebih lemah terhadap pengusaha. Rendah atau lemahnya posisi tawar pekerja dapat terjadi selain karena kebutuhan pekerja atas lapangan kerja di saat kesempatan kerja menyempit, kohesivitas yang relatif rendah antar pekerja dan juga akibat tingkat kekuatan tawar menawar dan kebijakan manajemen dalam hal pengelolaan sumber daya manusia yang mewarnai hubungan kedua belah pihak. Oleh karena itu, agar penyimpangan dan persoalan hubungan kerja berkurang, maka hubungan kerja yang ada perlu diperkuat dengan perjanjian kerja baik bersifat individual maupun bersifat kolektif. Namun perjanjian kerja tersebut masih menyisakan permasalahan, antara lain sifatnya yang individual cenderung menciptakan kondisi berat sebelah sehingga relatif menguntungkan pengusaha. Selain itu perjanjian kerja dibuat secara sepihak oleh pengusaha yang memungkinkan isi perjanjian condong berpihak kepada pihak yang membuatnya sehingga lebih membatasi kepentingan pekerja. Terkait dengan permasalahan tersebut, hadirnya Perjanjian Kerja Bersama (selanjutnya dalam penelitian ditulis PKB) menjadi solusi terciptanya hubungan kerja yang baik. PKB ini disusun bersama oleh serikat pekerja dan pengusaha dimaksudkan dapat menyediakan perlindungan hak-hak normatif dan jaminan kerja yang lebih pasti bagi kedua pihak yakni pekerja dan pengusaha. Secara teknis operasional, keberadaan PKB telah diatur dalam Undang-Undang Nomor 13 tahun 2003 tentang Ketenagakerjaan (selanjutnya dalam penelitian ini 
ditulis UU No.13 Tahun 2003) terutama jika pada perusahaan terdapat serikat pekerja yang menghendaki disusunnya PKB. Kebersamaan dalam menyusun PKB timbul karena pengusaha menggunakan pandangan bersama (collectivism) yang mana pengusaha mendukung serikat pekerja sebagai organisasi yang merepresentasikan pekerja.

Meskipun PKB secara teknis operasionalnya telah diatur oleh UU No. 13 tahun 2003, namun demikian kekuatan hukum dan kualitas isi atau substansi PKB masih perlu diuji. Ketimpangan dalam perjanjian bukan hanya soal kurang memadainya pemahaman pengusaha dan pekerja dalam menyusun PKB, melainkan pula kurangnya pemahaman akan peran pentingnya dan kekuatan hukum PKB. PKB dibuat oleh pengusaha bersama serikat pekerja melalui proses perundingan yang berisikan syaratsyarat kerja dan mengatur hubungan antara pengusaha dengan serikat pekerja dan pekerja mengetahui hak dan kewajibannya masing-masing. ${ }^{1}$

Problematika yang masih dihadapi adalah masih lemahnya perlindungan hukum terhadap pekerja dalam hubungan industrial. Banyak produk-produk PKB justru mengorbankan pekerja dan menguntungkan pengusaha, karena dari sisi posisi tawar pekerja memang lebih lemah dari pengusaha. PKB sebagai salah satu sarana hubungan industrial seyogyanya menempatkan PKB sebagai sarana untuk menjamin perlindungan hak-hak normatif pekerja. Secara yuridis perlu dicermati bahwa PKB merupakan sarana hubungan industrial dan merupakan rujukan kaidah atau norma tata kelola hubungan industrial dalam hubungan kerja antara pekerja dan pengusaha di perusahaan. Problematika yuridisnya adalah walaupun dalam UU No. 13 tahun 2003 telah mengatur ketentuan-ketentuan PKB secara teknis, namun tidak ada pengaturan lebih lanjut yang menyatakan bahwa PKB memiliki kekuatan hukum yang semestinya dirumuskan secara kongkret, jelas dan tegas. Ketiadaan pengaturan kekuatan hukum yang dimaksud, para pihak yakni pengusaha dan pekerja akan menafsirkan secara berbeda-beda menempatkan kedudukan hukum PKB dalam perusahaan.

Sebagai salah satu sarana hubungan industrial, PKB secara teknis diatur pada BAB XI, Bagian Ketujuh, Pasal 116 sampai dengan Pasal 133

1 Budi Santoso, Budi Santoso, 2012, Hukum Ketenagakerjaan Perjanjian Kerja Bersama Teori Cara pembuatan dan Kasus, Cetakan ke 1, UB Press, Malang, h.3 
dalam UU No. 13 tahun 2003. PKB sebagai rujukan hukum dalam tata kelola perusahaan yang baik (good coorporate governance), namun kekuatan hukum PKB tidak dinyatakan secara kongkrit, tegas dan jelas dalam bentuk rumusan hierarki peraturan terkait dengan hubungan kerja dalam UU No. 13 tahun 2003. IImu perundang-undangan menyatakan bahwa setiap peraturan perundang-undangan jika dikatakan memiliki kekuatan hukum seyogyanya dirumuskan dalam bentuk hierarki peraturan sebagaimana hierarki peraturan perundang-undangan berdasarkan UU No. 12 Tahun 2011 tentang Pembentukan Peraturan Perundang-undangan (selanjutnya dalam penelitian ini ditulis UU No. 12 Tahun 2011).

Jika dicermati secara mendalam terdapat dikotomi antara PKB dengan peraturan perusahan dalam UU No. 13 Tahun 2003. Kita mengetahui bersama bahwa PKB dan peraturan perusahan merupakan rujukan hukum perjanjian kerja individual baik itu Perjanjian Kerja Waktu Tertentu (PKWT) dan Perjanjian Kerja Waktu Tidak Tertentu (PKWTT). Namun demikian, yang termaktud dalam UU No. 13 Tahun 2013 antara PKB dengan peraturan perusahan seolah-olah dua produk hukum hubungan kerja yang terpisahkan dan tidak memiliki hubungan hukum. Padahal dalam tahap implementasi peraturan perusahan merupakan aturan teknis pelaksanaan dari PKB. PKB dapat diibaratkan sebagai sebuah grundnorm (norma dasar) yang tidak dapat dipungkiri memerlukan sebuah aturan teknis pelaksanaan, baik itu dalam bentuk peraturan (regeling) maupun keputusan (beschikking). Salah satu dari peraturan (regeling) yang dibutuhkan PKB itu sendiri adalah peraturan perusahan selain juga keputusan-keputusan pengusaha untuk mengkonkretkan klausul-klausul dasar yang diatur dalam PKB. Penelusuran terhadap UU No. 13 Tahun 2003, dapat dicermati sebuah fakta hukum bahwa tidak terakomodirnya hubungan hukum antara PKB dengan peraturan perusahan. Berkenaan dengan hal tersebut di atas, terdapat isu hukum normatif yaitu adanya sebuah kekosongan kekuatan hukum karena ketiadaan hierarki peraturan-peraturan terkait dengan hubungan kerja dalam hubungan industrial. Berdasarkan ilmu perundang-undangan kekuatan hukum itu terletak pada hierarki peraturan, yang menjadikan setiap aturan-aturan hubungan kerja dalam hubungan industrial memiliki hubungan hukum secara vertikal. Ilmu perundang-undangan secara sistem 
tidak menghendaki adanya peraturan yang tidak jelas, tidak tegas, tidak harmonis. Sebuah perundang-undangan yang terintegrasi menjadi sangat diperlukan untuk mewujudkan ketertiban dan perlindungan hukum. Seyogyanya, sebuah konsep hierarki peraturan tersebut dapat menjembatani hubungan hukum antara peraturan-peraturan hubungan hubungan kerja dalam hubungan industrial. Hal tersebut dapat memberikan jaminan kekuatan hukum dari peraturan-peraturan hubungan kerja.

Sebagaimana karakteristik dari penelitian hukum normatif, maka pencermatan dari peraturan perundang-undangan yang ada, menunjukkan adanya kekosongan norma (recht vacuum) tentang kekuatan hukum peraturan-peraturan berkaitan dengan hubungan kerja dalam UU No. 13 tahun 2003 yang belum dirumuskan dalam bentuk hierarki peraturan perundang-undangan. Secara ilmu perundang-undangan menyatakan tingkatan kekuatan hukum dalam sebuah peraturan jika sebuah hierarki peraturan dirumuskan secara konkrit, jelas dan tegas. Jika hal tersebut tidak ada, PKB sebagai bagian dari peraturan hubungan kerja sekaligus menjadi sarana dalam hubungan Industrial, memiliki potensi kedudukan hukum yang lemah, yang pada akhirnya dapat menimbulkan lemahnya perlindungan hak-hak normatif pekerja.

Berdasarkan uraian di atas, penulis akan mengkaji dalam sebuah penelitian hukum yang berjudul: "Rekonstruksi Perjanjian Kerja Bersama Dalam Undang-Undang Nomor 13 Tahun 2003 Tentang Ketenagakerjaan“.

\section{TINJAUAN PUSTAKA}

\section{a. Konstruksi Hukum}

Konstruksi hukum terjadi apabila tidak ditemukan atau ketidaklengkapan ketentuan norma atau undang-undang yang secara langsung dapat diterapkan pada masalah hukum yang dihadapi, atau dalam hal peraturannya tidak ada, jadi terdapat kekosongan hukum (recht vacuum) atau kekosongan UU (wet vacuum). Metode Argumentasi atau penalaran hukum dipergunakan untuk menganalisa kekosongan atau ketidaklengkapan perundang-undangan. ${ }^{2}$ Untuk mengisi kekosongan atau

2 Ahmad Rifai, 2010, Penemuan Hukum oleh Hakim dalam Perspektif Hukum Progresif., Sinar Grafika, Jakarta, h.61. 
ketidaklengkapan perundang-undangan itu digunakan metode konstruksi hukum yaitu : argumentum per analogium (analogi), argumentum a contrario, penyempitan hukum dan fiksi hukum. ${ }^{3}$ Diperlukan sebuah argumentum per analogium apabila menghadapi peristiwa-peristiwa yang analog atau mirip. ${ }^{4}$ Tidak hanya sekedar kalau peristiwa yang akan diputus mirip dengan peristiwa yang diatur dalam undang-undang, tetapi juga apabila kepentingan masyarakat hukum menuntut penilaian yang sama. ${ }^{5}$

Penelitian hukum ini terdapat sebuah kekosongan hukum (recht vacuum) atau ketidaklengkapan perundang-undangan karena ketiadaan pengaturan kekuatan hukum PKB dalam UU No. 13 Tahun 2003, sehingga dibutuhkan pengkonkretan hukum dengan metode kontruksi hukum atau penalaran (redeneerweijzen) yang nantinya terbentuk norma baru yang dicita-citakan dan berlaku kelak.

\section{b. Teori Cita Hukum (Rechtsidee Theory)}

Teori cita hukum (rechtsidee) ini yang dikemukakan oleh Gustav Radbruch dipergunakan untuk menganalisis idealnya rumusan pengaturan ke depan terkait dengan kekuatan hukum PKB dalam UU No. 13 Tahun 2003 maupun PKB sebagai produk hukum hubungan kerja dalam hubungan industrial.

Teori cita hukum dapat dipahami sebagai suatu konstruksi pikiran yang merupakan keharusan untuk mengarahkan hukum pada cita-cita yang diinginkan masyarakat. Gustav Radbruch berpendapat bahwa cita hukum berfungsi sebagai tolok ukur yang bersifat regulatif dan konstitutif. Tanpa cita hukum maka produk hukum yang dihasilkan akan kehilangan makna. $^{6}$

Menurut Gustav Radbruch tersebut dapat dipahami melalui text aslinya sebagai berikut : ${ }^{7}$

3 Sudikno Mertokusumo, 2016, Mengenal Hukum Suatu Pengantar (Edisi Revisi), Cetakan ke 6, Cahaya Atma Pustaka, Yogyakarta, h.226.

4 Ibid, h.229

5 Ibid.

6 Esmi Warasih, 2010, Pranata Hukum Sebuah Telaah Sosiologi, PT Suryadaru Utama, Semarang,h.43.

7 Gustav Radbruch dalam Esmi Warasih, 2010, Pranata Hukum Sebuah 
De rechtidee niet alien a/seen regulatieve maatstaaf fungeert (om het positieve recht op zijn rechtvaardigheid op ojirechtvaardigheid to toetsen), maar tegelijk als constitutive grondslag (zonder welke het recht, dat de rechtidee der gerechtighoit de grondslag vormt van recht, dat met de idee in strijd kan zijn (onrechtvaardigrecht).

Kurang lebih terjemahannya sebagai berikut : Cita yang benar bukanlah suatu yang asing atau semata-mata suatu tolak ukur regulasi (dalam hak positif), melainkan pada saat yang bersamaan mencerminkan dasar konstitutif yang tanpa esensi hukum pembentukannya dapat mempertentangkan cita hukum dan hukum bentuknya (hukum yang tidak adil).

Berdasarkan hal tersebut di atas, setiap proses pembentukan dan penegakan serta perubahan-perubahan yang hendak dilakukan terhadap hukum tidak boleh bertentangan dengan cita hukum yang disepakati. Oleh karena itu Hans Kelsen menyebutkan cita hukum sebagai grundnorm atau basic norm. ${ }^{8}$

Lebih lanjut Gustav Radbruch mengemukakan terdapat 3 (tiga) nilai dasar dari hukum yang kemudian dikenal dengan cita hukum. Ketiga nilai tersebut yaitu kepastian, keadilan, kemanfaatan. Sebagai nilai dasar hukum (azas hukum) menempatkan ketiga nilai dasar hukum ini sebagai rujukan pertama dalam pembentukan peraturan perundang-undangan.

\section{c. Perjanjian Kerja Bersama}

Berdasarkan Pasal 1 angka 21 UU No. 13 Tahun 2003 jo Permenakertrans No. 28/MEN/2014 tentang Tata Cara Pembuatan Dan Pengesahan Peraturan Perusahaan Serta Pembuatan Dan Pendaftaran Perjanjian Kerja Bersama, Pengertian Perjanjian Kerja Bersama (PKB) adalah perjanjian yang merupakan hasil perundingan antara serikat pekerja/serikat buruh atau beberapa serikat pekerja/serikat buruh yang tercatat pada instansi yang bertanggung jawab di bidang ketenagakerjaan dengan pengusaha, atau beberapa pengusaha atau perkumpulan pengusaha yang memuat syarat syarat kerja, hak dan kewajiban kedua belah pihak.

\section{METODE PENELITIAN}

\section{a. Desain Penelitian}

Telaah Sosiologi, PT Suryadaru Utama, Semarang, h.43.

$8 \mathrm{lbid}$, h.46 
Penelitian ini mengangkat masalah kekosongan hukum dalam UU No. 13 tahun 2003 yang berkorelasi dengan ketiadaan pengaturan kekuatan hukum PKB. Rumusan permasalahan yaitu : Bagaimana rekonstruksi PKB dalam UU No. 13 tahun 2003 sehingga dapat memberikan jaminan cita hukum dalam hubungan industrial?. Tujuan dan kegunaan penelitian adalah untuk mengetahui dan mengkaji permasalahan yang diangkat. Teori hukum yang digunakan adalah Teori Cita Hukum, Teori Jenjang Norma, Teori Keadilan, dan Teori Perlindungan Hukum. Jenis penelitian hukum tesis ini bersifat penelitian hukum normatif. Penelitian hukum normatif ini menggunakan pendekatan perundangundangan, pendekatan konsep dan pendekatan analisis.

Oleh karena itu penulis tertarik untuk mengkaji permasalahan dengan desain penelitian ini agar dapat dipahami untuk menjawab rumusan permasalahan di atas.

\section{b. Jenis dan Sumber Data}

Jenis Penelitian yang dilakukan kaitannya dalam penulisan tesis ini merupakan penelitian hukum normatif. Sumber data yang digunakan dalam penelitian ini adalah jenis data sekunder.

(1) Data Sekunder.

Menurut Soerjono Soekanto, data sekunder antara lain mencakup dokumen-dokumen resmi, buku-buku, hasil-hasil penelitian yang berwujud laporan, buku harian dan seterusnya. ${ }^{9}$

Adapun jenis data sekunder yang digunakan adalah sebagai berikut :

a) Bahan Hukum Primer

Bahan hukum primer adalah bahan hukum yang mempunyai kekuatan hukum mengikat secara umum. ${ }^{10}$ Bahan hukum primer juga termasuk bahan hukum yang bersifat autoritatif artinya bahan hukum yang memiliki otoritas. ${ }^{11}$

9 Soerjono Soekanto, 2015, Pengantar Penelitian Hukum, Cetakan ke 3, UI Press, Jakarta, h.7.

${ }^{10}$ Soerjono Soekanto dan Sri Pamudji, 2015, Penelitian Hukum Normatif Suatu Tinjauan Singkat, Cetakan ke 15, PT Raja Grafindo Persada, Jakarta,h.13.

${ }^{11}$ Peter Mahmud Marzuki, 2016, Penelitian Hukum Edisi Revisi, Cetakan ke 12., Kencana, Jakarta,h.181. 
Menurut Morris L. Cohen, yang dimaksud dengan bahan hukum primer adalah "Primary source are the court decisions, statute, and regulations that form the basis of the legal doctrine". ${ }^{12}$ Kurang lebih terjemahan sebagai berikut : Bahan hukum primer adalah keputusan pengadilan, undang-undang dan peraturan yang menjadi dasar doktrin hukum.

Adapun bahan hukum primer yang dipergunakan untuk mengkaji permasalahan dalam penelitian ini bersumber dari :

1. Undang-Undang Dasar Negara Republik Indonesia 1945

2. Undang-Undang Nomor 21 Tahun 2000 tentang Serikat Pekerja/Serikat Buruh (Lembaran Negara Republik Indonesia Tahun 2000 Nomor 131, Tambahan Lembaran Negara Republik Indonesia Nomor 3989).

3. Undang-Undang Nomor 13 Tahun 2003 (Lembaran Negara Republik Indonesia Tahun 2003 Nomor 39, Tambahan Lembaran Negara Republik Indonesia Nomor 4279).

4. Undang-Undang Nomor 2 Tahun 2004 tentang Penyelesaian Perselisihan Hubungan Industrial (Lembaran Negara Republik Indonesia Tahun 2004 Nomor 6, Tambahan Lembaran Negara Republik Indonesia Nomor 4356).

5. Undang-Undang Nomor 12 Tahun 2011 tentang Pembentukan Peraturan Perundang-undangan (Lembaran Negara Republik Indonesia Tahun 2011 Nomor 82).

6. Peraturan Menteri Ketenagakerjaan Republik Indonesia Nomor 28 Tahun 2014 tentang Tata Cara Pembuatan dan Pengesahan Peraturan Perusahaan serta Pembuatan dan Pendaftaran PKB

b) Bahan Hukum Sekunder

Bahan hukum Sekunder adalah bahan pustaka yang memberikan penjelasan mengenai bahan hukum primer. ${ }^{13}$ Morris L. Cohen lebih lanjut mengatakan bahwa yang dianggap bahan hukum sekunder sebagai berikut : Works which are not themselves the law, but which discuss or analyze legal doctrine, are considered secondary source. These included treatises,

12 Morris L. Cohen and Kent C. Olson, 2000, Legal Research In A Nutshell, Seventh Edition, St Pul Minn : West Publishing Co., h.7.

${ }^{13}$ Peter Mahmud Marzuki, op. cit., h.182 
hornbooks, restatement, and practice manuals. Much of the most influential legal writing is found in academic journals known as law reviews. ${ }^{14}$ Kurang lebih terjemahannya adalah karya yang bukan merupakan hukum sendiri, tapi yang membahas atau menganalisa doktrin hukum, dianggap sebagai bahan hukum sekunder. Ini termasuk risalah, buku catatan, penyajian kembali, dan panduan praktik. Sebagian besar tulisan hukum paling berpengaruh ditemukan di jurnal akademis yang dikenal sebagai ulasan hukum.

Adapun bahan hukum sekunder yang digunakan adalah bersumber dari buku-buku atau literatur-literatur hukum, jurnal hukum, kamus (dictionary) yang relevan dengan permasalahan yang diteliti.

\section{c. Teknik Pengumpulan Data}

Teknik pengumpulan data yang dipergunakan dalam penulisan ini dilakukan dengan teknik dokumentasi dan teknik snowball. Teknik tersebut adalah untuk menggali kerangka normatif menggunakan bahan hukum melalui dokumentasi teori-teori hukum, asas-asas hukum, tentang kekuatan hukum PKB, perlindungan hukum dan keadilan pekerja dalam hubungan industrial. Bahan-hukum primer dan sekunder dikumpulkan dengan studi kepustakaan atau studi dokumen. Studi pustaka atau studi dokumen dilakukan untuk mencari, mempelajari dan menelaah berbagai bahan hukum, selanjutnya disusun dan dikelompokkan sesuai dengan permasalahan yang diteliti dan diklasifikasikan berdasarkan pengumpulan bola salju (Snow ball) sehingga bahan-bahan hukum siap untuk dikaji secara komprehensif.

\section{d. Teknik Analisis Data}

Terhadap data yang diperoleh dari penelitian ini kemudian dianalisis secara deduktif dengan metode atau teknik penafsiran dan konstruksi hukum. Teknik analisis data terhadap bahan-bahan hukum tersebut, dilakukan dengan cara deskriptif, interpretatif dan argumentatif. Bahan hukum dianalisis dan disusun secara sistematis dan dilakukan pendeskripsian atau penggambaran bahan-bahan hukum sebagaimana adanya, memberikan penafsiran dan mengkonstruksikan peraturan perundang-undangan yang terkait dengan permasalahan yang diangkat serta memberikan argumentasi hukum.

${ }^{14}$ Morris L. Cohen, op.cit., h.7 


\section{PEMBAHASAN}

Rekonstruksi PKB memberikan jaminan Cita Hukum dalam UU No. 13 Tahun 2003 tentang Ketenagakerjaan

Gustav Radbruch berpendapat bahwa peraturan perundangundangan idealnya memenuhi aspek kepastian, keadilan dan kemanfaatan. Gustav Radbruch lebih lanjut mengatakan bahwa cita hukum berfungsi sebagai tolok ukur yang bersifat regulatif dan konstitutif. Tanpa cita hukum maka produk hukum yang dihasilkan akan kehilangan makna. ${ }^{15}$ Berkenaan dengan permasalahan hukum yang diangkat dalam penelitian ini terkait dengan rekonstruksi PKB dalam UU No. 13 Tahun 2003 tentang Ketenagakerjaan, penelitian hukum ini dilakukan untuk menggali dan menganalisa apakah PKB dalam UU No. 13 Tahun 2003 telah memenuhi unsur kepastian hukum, keadilan dan kemanfaatan hukum. Penelitian hukum yang dilakukan adalah penelitian hukum normatif yang tujuannya untuk menggali dan memecahkan permasalahan hukum, dan hasil yang hendak dicapai adalah memberikan preskripsi mengenai apa seyogyanya.

Berdasarkan teori Gustav Radbruch tersebut yang menyatakan bahwa hukum harus memiliki tiga aspek yakni kepastian, keadilan dan kemanfaatan antara lain : Aspek kepastian menunjuk pada hukum benarbenar berfungsi sebagai peraturan yang ditaati. Aspek keadilan menunjuk pada kesamaan hak dalam hukum. Sedangkan aspek kemanfaatan hukum menunjuk pada memajukan kebaikan dalam hidup manusia. Teori cita hukum oleh Gustav Rudbruch inilah sebagai teori utama yang digunakan dalam membedah secara universal permasalahan yang diangkat, yang selanjutnya dibedah dan dikonkretkan menggunakan teori-teori pendukung dari teori utama seperti teori jenjang norma oleh Hans Kelsen, teori keadilan oleh John Rawl dan teori perlindungan hukum oleh Phillipus M. Hadjon.

Berikut di bawah ini analisis-analis berdasarkan Teori Cita Hukum dari aspek kepastian, keadilan dan kemanfaatan tersebut adalah :

${ }^{15}$ Esmi Warasih, loc.cit, h.43 


\section{Rekonstruksi PKB memberikan aspek kepastian hukum dalam hubungan industrial}

Adanya kekosongan atau ketiadaan pengaturan kekuatan hukum peraturan-peraturan terkait dengan hubungan kerja dalam UU No. 13 Tahun 2003, perlu dibuatkan pengaturannya melalui konstruksi hukum agar tidak terdapat kekosongan hukum. Hal tersebut dilakukan untuk menjamin adanya sebuah kepastian hukum. Konstruksi hukum terjadi apabila tidak ditemukan atau ketidaklengkapan ketentuan norma atau UU yang secara langsung dapat diterapkan pada masalah hukum yang dihadapi, atau dalam hal peraturannya tidak ada, terdapat sebuah kekosongan hukum (recht vacuum) atau kekosongan UU (wet vacuum). Ketentuan UU tidak dapat diterapkan begitu saja secara langsung pada peristiwanya. Untuk dapat menerapkan ketentuan UU yang berlaku umum dan abstrak pada peristiwa yang konkret dan khusus, ketentuan UU itu diberikan arti, dijelaskan atau ditafsirkan, diberikan penalaran, diberikan arahan atau disesuaikan dengan peristiwanya untuk kemudian baru diterapkan pada peristiwanya.

Sehubungan dengan telah diaturnya PKB hanya sebatas syaratsyarat dan proses pembuatan serta operasionalnya dalam UU No.13 Tahun 2003, maka dibutuhkan sebuah rekonstruksi hukum (pembentukan hukum kembali) terkait dengan PKB dalam UU No. 13 Tahun 2013. Pencermatan terhadap UU No. 13 Tahun 2003 berkenaan dengan PKB, terdapat kekosongan hukum (recht vacuum) atau kekosongan UU (wet vacuum) tentang pengaturan kekuatan hukum dalam bentuk hierarki peraturan-peraturan hubungan kerja dalam hubungan industrial. Upaya yang dilakukan untuk mengisi kekosongan hukum (recht vacuum) adalah dengan jalan konstruksi hukum atau penalaran hukum. Diperlukan sebuah konstruksi hukum dengan cara argumentum per analogium apabila menghadapi peristiwa-peristiwa yang analog atau mirip. Tidak hanya sekedar kalau peristiwa yang akan diputus mirip dengan peristiwa yang diatur dalam UU, tetapi juga apabila kepentingan masyarakat hukum menuntut penilaian yang sama.

Berkaitan dengan permasalahan hukum yang dikaji dalam penelitian ini, argumentum per analogium inilah yang dapat dijadikan metode kontruksi hukum dalam pembentukan norma baru terkait dengan 
pengaturan kekuatan hukum PKB dalam UU No. 13 Tahun 2003. Prinsip dasar dalam teori hierarki norma oleh Hans Kelsen yakni norma memiliki susunan berjenjang tersebut adalah norma fundamental negara (staatsfundamentalnorm); aturan dasar negara (staatsgrundgezets); undang-undang formal (formellgezets); dan peraturan pelaksanaan dan peraturan otonom (verordnung en autonome satzung) menjadi landasan analisis terbentuknya sebuah hierarki peraturan yang mencerminkan kekuatan hukum. Norma yang dicita-citakan kelak terkait dengan rumusan kekuatan hukum dianggap peristiwa hukumnya mirip atau sama, sehingga sangat relevan mempergunakan rumusan hierarki peraturan perundangundangan dalam UU No. 12 Tahun 2011 sebagai analogi hukum karena disamping peristiwanya hukumnya mirip atau sama, UU No. 12 Tahun 2011 ini juga UU yang menjadi referensi para pembentuk UU (eksekutif dan legislatif) dalam merancang dan membentuk peraturan perundangundangan.

Adapun hierarki peraturan perundang-undangan dalam UU No. 12 Tahun 2011 sebagai berikut :

1) UUD 1945, merupakan "hukum dasar" dalam Peraturan Perundang - undangan. UUD 1945 ditempatkan dalam Lembaran Negara Republik Indonesia.

2) Ketetapan MPR

3) Undang-Undang (UU) / Peraturan Pemerintah Pengganti Undang -Undang (Perpu)

4) Peraturan Pemerintah (PP)

5) Peraturan Presiden (Perpres)

6) Peraturan Daerah (Perda), termasuk pula 'Qanun" yang berlaku di Nanggroe Aceh Darussalam, serta 'Perdasus" dan 'Perdasi' yang berlaku di Provinsi Papua dan Papua Barat.

Berdasarkan UU No. 13 Tahun 2003, Pasal 54 dan Pasal 128 mengatur hubungan hukum antara peraturan-peraturan terkait dengan hubungan kerja dalam hubungan industrial seperti halnya PKB, peraturan perusahan dan perjanjian kerja. Namun hubungan hukum tidak diatur dalam satu kesatuan rumusan hierarki yang sistematis dan tidak terdapat pengaturan rumusan dalam bentuk hierarki atau perjenjangan norma. Ketentuan tersebut hanya menyebutkan bahwa perjanjian kerja tidak boleh 
bertentangan dengan peraturan perusahan, perjanjian kerja bersama dan peraturan perundang-undangan yang berlaku. Apabila isi atau muatan dari perjanjian kerja, peraturan perusahan bertentangan dengan perjanjian kerja bersama, maka ketentuan-ketentuan tersebut batal demi hukum dan ketentuan yang berlaku adalah ketentuan dari perjanjian kerja bersama.

Jika dicermati secara mendalam dalam UU No. 13 Tahun 2003 tersebut, terdapat dikotomi antara PKB dengan peraturan perusahan. Kita mengetahui bersama bahwa PKB dan peraturan perusahan merupakan rujukan hukum perjanjian kerja individual baik itu Perjanjian Kerja Waktu Tertentu (PKWT) dan Perjanjian Kerja Waktu Tidak Tertentu (PKWTT). Namun demikian, berdasarkan UU No. 13 Tahun 2013 antara PKB dengan peraturan perusahan seperti dua buah produk hukum hubungan kerja yang terpisahkan dan tidak memiliki hubungan hukum. Padahal dalam tahap implementasi, peraturan perusahan merupakan aturan teknis pelaksanaan dari PKB. PKB dapat diibaratkan sebagai sebuah grundnorm (norma dasar) yang tidak dapat dipungkiri memerlukan sebuah aturan teknis pelaksanaan, baik itu dalam bentuk peraturan (regeling) maupun keputusan (beschikking). Salah satu dari peraturan (regeling) yang dibutuhkan PKB adalah peraturan perusahan itu sendiri, selain juga keputusan-keputusan pengusaha untuk mengkonkretkan klausul-klausul dasar yang diatur dalam PKB. Pencermatan dari fakta hukum demikian, bahwa terdapat sebuah fakta dalam UU No. 13 Tahun 2003, tidak terakomodirnya ketentuan terkait dengan hubungan hukum antara PKB dengan peraturan perusahan. Akibat dari hal tersebut dalam tahap implementasi seringkali terjadi konflik hukum terkait dengan rujukan hukum yang digunakan dalam pembuatan perjanjian kerja yang bersifat individual. Hal ini karena ketiadaan pengaturan kekuatan hukum diantara peraturan-peraturan hubungan kerja. Berkenaan dengan hal tersebut, terdapat isu hukum normatif yaitu adanya sebuah kekosongan kekuatan hukum tentang ketiadaan hierarki peraturanperaturan terkait dengan hubungan kerja dalam hubungan industrial. Berdasarkan ilmu perundang-undangan kekuatan hukum itu terletak pada hierarki peraturan, yang menjadikan setiap aturan-aturan ketentuan hubungan kerja dalam hubungan industrial memiliki hubungan hukum secara vertikal. IImu perundang-undangan secara sistem tidak menghendaki adanya peraturan yang tidak jelas, tidak tegas, tidak 
harmonis. Sebuah perundang-undangan yang terintegrasi menjadi sangat diperlukan untuk mewujudkan ketertiban dan perlindungan hukum. Seyogyanya sebuah konsep hierarki peraturan itu dapat menjembatani hubungan hukum antara peraturan-peraturan hubungan kerja dalam hubungan industrial. Hal tersebut dapat memberikan jaminan kepastian hukum dari setiap peraturan-peraturan hubungan kerja.

Untuk mengkonstruksikan hal tersebut, berdasarkan metode analogi (argumentum per analogium) dalam pembentukan norma yang dicitacitakan, dengan menganalogikan pengaturan kekuatan hukum hierarki perundang-undangan dalam UU No. 12 Tahun 2011 ke dalam konsep norma baru dalam UU No.13 Tahun 2003, maka dapat dirumuskan norma baru atau norma yang dicita-citakan yang mengatur kekuatan hukum dalam bentuk hierarki atau perjenjangan peraturan-peraturan hubungan kerja yang tertuang nantinya dalam rumusan baru dalam UU No. 13 Tahun 2003.

Adapun rumusan pengaturan yang dicita-citakan bahwa Peraturan yang berada pada tingkat tertinggi adalah PKB, selanjutnya di bawah PKB adalah peraturan perusahan yang keseluruhan peraturan-peraturan berlaku bagi seluruh pekerja atau karyawan di perusahan yang bersangkutan. Selanjutnya di bawah peraturan perusahan adalah perjanjian kerja yakni peraturan yang berlaku untuk individu baik untuk waktu tertentu atau untuk waktu tidak tertentu. PKB memiliki kekuatan hukum tertinggi atau berkedudukan yang paling tinggi dari peraturan-peraturan hubungan kerja yang lain karena perjanjian kerja bersama memiliki cakupan hukum lebih luas dan abstrak dari peraturan perusahan dan perjanjian kerja. Secara teori hierarki norma menyatakan bahwa kedudukan kekuatan hukum sangat jelas dan tegas yakni peraturan yang lebih rendah tidak boleh bertentangan dengan peraturan yang lebih tinggi dan peraturan yang lebih tinggi menjadi rujukan peraturan yang lebih rendah. Adapun konsep rumusan norma yang dicita-citakan kelak tentang kekuatan hukum dalam bentuk hierarki peraturan berkenaan dengan hubungan kerja dalam hubungan industrial ini, akan diatur pasal tersendiri dalam UU No. 13 Tahun 2003 sebagai berikut :

Pasal ....

Jenis dan hierarki peraturan hubungan kerja dalam hubungan industrial terdiri atas :

1) Perjanjian kerja bersama

2) Peraturan perusahan 
3) Perjanjian kerja individual (waktu tertentu dan waktu tidak tertentu)

\section{Rekonstruksi PKB memberikan aspek keadilan dalam hubungan industrial}

Menurut pandangan Gustav Radbruch, kepastian hukum saja tidak cukup, pencermatan terhadap pembentukan perundang-undangan harus tetap mempertimbangan nilai keadilan pada setiap substansi dalam ketentuan perundang-undangan yang pada nantinya perundang-undangan memiliki kemanfaatan dalam masyarakat. Gustav Radbruch tidak mempertentangkan ketiga nilai dasar yakni antara kepastian, keadilan dan kemanfaatan, namun idealnya yang diinginkan dari cita hukum menurut Gustav Radbruch adalah ketiga nilai dasar tersebut sinergis dan proporsional.

PKB merupakan perjanjian yang dihasilkan melalui perundingan dan tetap tunduk terhadap asas-asas hukum perjanjian. Selain memiliki kepastian hukum, PKB dalam setiap kesepakatan-kesepakatan yang dilakukan antara pengusaha dan serikat pekerja seyogyanya tetap dijiwai oleh prinsip-prinsip keadilan terhadap kaum pekerja. Lebih lanjut dikatakan bahwa tidak hanya jaminan kekuatan hukum PKB dalam UU No. 13 Tahun 2003 saja, akan tetapi muatan atau isi PKB yang disepakati pun tidak kalah penting. Apa yang telah disepakati dan diatur dalam PKB dapat diimplementasikan melalui komitmen yang sungguh-sungguh dari pihak pengusaha serta dukungan dari pihak serikat pekerja. Hal tersebut dapat dikatakan bahwa jaminan keadilan harus terwujud dalam realitas implementatif. Berdasarkan konteks ini, maka peranan PKB adalah menjamin dan memastikan bahwa prinsip keadilan setiap klausul-klausul kesepakatan dapat terwujud dalam hubungan kerja. PKB harus menciptakan prosedur normatif yang adil bagi pekerja dalam meraih kesejahteraan.

Menurut John Rawls seorang filsuf dari Amerika Serikat pada abad ke-20, mengemukakan keadilan sebagai berikut :

First Principles. Each person is to have an equal right to the most extensive total system of equal basic liberties compatible with a similar system of liberty for all. Second Principle. Social and economic inequalities are to be arranged so that they are both: (a) to the greatest benefit of the least advantaged, consistent with the just saving principle, and (b) attached to offices and positions open to all 
under conditions of fair equality of opportunity. ${ }^{16}$ Kurang lebih terjemahannya adalah Prinsip pertama. Setiap orang memiliki hak yang seimbang terhadap keseluruhan sistem kebebasan dasar yang seimbang sesuai dengan sistem kebebasan untuk semua orang. Prinsip kedua: (a) untuk manfaat bagi keuntungan yang terbesar, konsisten dengan prinsip keuntungan, dan (b) melekat pada jabatan dan kedudukan terbuka untuk semua kondisi persamaan keseimbangan yang adil).

Prosedur yang adil dalam meraih kesejahteraan, menurut John Rawls tersebut di atas mengusulkan prosedur berlapis berkenaan dengan prinsip keadilan. Pertama-tama, prinsip persamaan yang adil atas kesempatan (the principle of fair equality of opportunity). Artinya akses terkait kesejahteraan dibuka sama luas bagi semua orang. Setiap orang tanpa kecuali berhak meraih kesejahteraan. Tetapi jika masih menemukan nilai ketidakadilan maka prosedur kedua harus ditempuh yakni prinsip perbedaan (the difference principle). Artinya, bahwa perbedaan sosial dan ekonomi harus diatur sedemikian rupa agar memberi manfaat yang paling besar bagi mereka yang kurang beruntung. ${ }^{17}$

Prinsip keadilan yang kedua inilah yang sangat penting artinya dalam klausul-klausul kesepatan perjanjian yang disepakati dalam PKB dan menjiwai pelaksanaan hubungan kerja dalam hubungan industrial. Ketika ada ketimpangan dalam hal pengaturan kesejahteraan maka harus diatur sedemikian rupa. Para pihak yang melakukan perundingan PKB yakni pengusaha dan serikat pekerja harus sepakat memberikan perlindungan dengan mengedepankan keadilan baik itu dari sisi kesejahteraan dan kenyaman kerja bagi pekerja sebagai pihak yang memiliki posisi tawar lebih lemah dari pengusaha dalam hubungan industrial. PKB sebagai sarana hubungan industrial dengan segala keterbatasan yang ada, harus memperhatikan dan menjadi dasar pertimbangan dalam mewujudkan hubungan kerja yang harmonis, dinamis, dan berkeadilan.

16 John Rawls, 1971, A Theory of Justice, The Belknap Press of Havard University Press, Cambridge Massachusetts,h.302.

17 Bernand L. Tanya, 2013,Teori Hukum Strategi Tertib Manusia Lintas Ruang dan Waktu, Cetakan ke 4, Genta Publishing, Yogyakarta, h.87. 


\section{Rekonstruksi PKB memberikan aspek kemanfaatan hukum dalam hubungan industrial}

PKB sebagai produk hukum hubungan industrial diharapkan pula akan memberikan kemanfaatan kepada para pemangku kepentingan (stake holder) hubungan kerja dalam hubungan industrial. Kemanfaatan hukum yang dimaksud adalah PKB dapat bermanfaat memberikan perlindungan hukum khususnya terhadap pekerja, karena pekerja secara status sosial dan ekonomi dalam hubungan kerja selalu berada dalam posisi dan daya nilai tawar yang lebih lemah daripada pengusaha.

Menurut Philipus M. Hajon, perlindungan hukum dibedakan menjadi 2 yaitu perlindungan hukum preventif dan perlindungan hukum refresif. ${ }^{18}$ Perspektif perlindungan hukum dari Philipus M. Hajon ini memiliki relevansi kemanfaatan hukum berkenaan dengan peran PKB dalam hubungan industrial. Peran pemerintah memberikan pengawasan dalam memberikan pengakuan berlakunya UU No. 13 Tahun 2003 dalam PKB atas diterbitkan akta pendaftaran sehingga PKB sah menjadi produk hukum hubungan industrial yang memberikan perlindungan preventif terhadap pekerja. Hal ini merupakan wujud perlindungan preventif yang diberikan pemerintah terhadap keberlangsungan hubungan kerja dalam hubungan industrial. Lebih lanjut menurut Imam Soepomo, perlindungan pekerja dibagi menjadi 3 (tiga) macam yang menjiwai perlindungan preventif yaitu: ${ }^{19}$

1) Perlindungan ekonomis yaitu perlindungan pekerja dalam bentuk penghasilan yang cukup, termasuk bila pekerja tidak mampu bekerja di luar kehendaknya

2) Perlindungan sosial yaitu perlindungan pekerja dalam bentuk jaminan kesehatan, dan kebebasan berserikat dan perlindungan hak untuk berorganisasi

3) Perlindungan teknis yaitu perlindungan pekerja dalam bentuk keamanan dan kesehatan kerja.

Perlindungan ekonomis, sosial dan teknis di atas inilah menjadi filosofi dan tolok ukur perlindungan hukum secara preventif yang dikemukanan oleh Phillipus M Hadjon. Pengaturan perlindungan pekerja

18 Philipus M. Hadjon, 2015, Perlindungan Hukum Bagi Rakyat di Indonesia, Cetakan ke 5, PT Bina IImu, Surabaya, h.25.

${ }^{19}$ Imam Soepomo, 2016, Hukum Perburuhan Bidang Hubungan Kerja, Cetakan ke 7, Djambatan, Jakarta,h.43. 
tersebut menjiwai PKB dalam realitas implementatif. Hal tersebut dapat dikatakan bahwa peran PKB dapat memberikan perlindungan hukum preventif yang memiliki nilai kemanfaatan hukum dalam hubungan industrial. PKB yang memiliki karakteristik kandungan hukum privat berdimensi hukum publik ditunjukkan dalam hal ketiga pengaturan perlindungan pekerja sebagaimana dikemukakan oleh Imam Soepomo.

Disamping itu PKB juga memberikan perlindungan represif yang artinya perlindungan hukum yang bertujuan untuk menyelesaikan perselisihan atau sengketa. Domain perselisihan hubungan industrial yang diatur dalam PKB yang merupakan amanat dari UU No. 2 Tahun 2004 tentang Penyelesaian Perselisihan Hubungan Industrial (selanjutnya ditulis UU No. 2 Tahun 2004) yakni perselisihan hak, perselisihan kepentingan, dan Pemutusan Hubungan Kerja (PHK). Adapun yang dimaksud dengan perselisihan-perselisihan hubungan industrial tersebut adalah : 20

1) Perselisihan hak adalah perselisihan yang timbul karena tidak dipenuhi hak akibat adanya perbedaan pelaksanaan atau penafsiran terhadap ketentuan perarturan perundang-undangan, perjanjian kerja, peraturan perusahan, atau perjanjian kerja bersama (pasal 1 angka 2 UU No. 2 Tahun 2004)

2) Perselisihan kepentingan adalah perselisihan yang timbul karena hubungan kerja karena tidak adanya kesesuaian pendapat mengenai pembuatan dan atau syarat-syarat kerja yang ditetapkan dalam perjanjian kerja atau peraturan perusahan atau perjanjian kerja bersama (Pasal 1 angka 3 UU No. 2 Tahun 2004)

3) Perselisihan Pemutusan Hubungan Kerja (PHK) adalah perselisihan yang timbul karena tidak adanya kesesuaian pendapat pengenai pengakhiran hubungan kerja yang dilakukan oleh salah satu pihak (pasal 1 angka 4 UU No. 2 Tahun 2004)

PKB memuat rekomendasi bahwa mekanisme penyelesaian perselisihan hubungan industrial dan selalu mengupayakan penyelesaian di luar pengadilan melalui mediasi, konsiliasi, dan arbitrasi dengan tetap mempertimbangkan reputasi perusahan dan konflik yang terjadi tidak berkepanjangan. Mekanisme mulai dari pro yustisia sampai dengan

20 Lalu Husni, 2015, Pengantar Hukum Ketenagakerjaan, Edisi Revisi Cetakan ke 13, Raja Grafindo Persada, Jakarta, h.121. 
persidangan penyelesaian sengketa di luar pengadilan melalui mediasi, konsiliasi, dan arbitrasi sebagaimana diatur dalam UU No. 2 Tahun 2004.

Nilai kemanfaatan hukum yang terkandung dalam hal penyelesaian perselisihan di luar pengadilan adalah memberikan jaminan penyelesaian perselisihan hubungan industrial akan berjalan damai dan menghasilkan win win solution yang tidak merugikan para pihak yang bersengketa yakni pengusaha dan pekerja

\section{PENUTUP}

\section{a. SIMPULAN}

Rekonstruksi PKB memberikan jaminan cita hukum yaitu jaminan atas kepastian hukum, keadilan dan kemanfaatan hukum berkenaan dengan hubungan industrial dalam UU No.13 Tahun 2003 antara lain :

1) Rekonstruksi PKB memberikan aspek kepastian hukum melalui konstruksi hukum dengan metode argumentum per analogium karena ketiadaan pengaturan kekuatan hukum PKB dalam UU No 13 Tahun 2003 sehingga terbentuk norma baru yang mengatur kekuatan hukum PKB. PKB merupakan sebuah perjanjian yang tunduk terhadap asas hukum perjanjian dalam KUH Perdata.

2) Rekonstruksi PKB memberikan aspek keadilan terhadap pekerja yang memiliki posisi tawar yang lebih lemah dari pengusaha

3) Rekonstruksi PKB memberikan aspek kemanfaatan hukum yang memberikan perlindungan hukum baik dalam bentuk preventif maupun refresif terhadap pekerja dalam hubungan industrial

\section{b. SARAN}

1) Pembentuk UU (eksekutif dan legislatif) seyogyanya merevisi UU No.13 Tahun 2003 tentang Ketenagakerjaan dengan menambah norma yang dicita-citakan terkait dengan rumusan kekuatan hukum peraturan hubungan kerja dalam bentuk hierarki peraturan. Hal ini sangat penting dilakukan, untuk menjamin agar PKB memiliki kepastian hukum berkenaan dengan PKB sebagai pedoman dalam tata kelola perusahan baik (good corporate governance). PKB dalam implementasinya pula menjadi norma rujukan (norma dasar) oleh norma lainnya terkait dengan hubungan kerja dalam hubungan industrial. 
2) Pihak pemerintah sebagai regulator agar selalu memiliki komitmen dalam melakukan pengawasan terhadap pelaksanaan hubungan industrial, ini termasuk upaya-upaya perlindungan preventif demi mewujudkan amanat konstitusi terkait jaminan warga negara yang memiliki hak dasar warga Negara terkait dengan penghidupan yang layak melalui hubungan kerja dalam hubungan industrial

3) Pemangku kepentingan (stake holder) yang terkait dengan hubungan kerja dalam hubungan industrial yakni pihak pengusaha, pekerja, dan serikat pekerja untuk dapat melaksanakan PKB dengan komitmen yang sungguh-sungguh untuk mewujudkan hubungan industrial yang harmonis, dinamis dan berkeadilan.

\section{DAFTAR PUSTAKA}

Buku:

Agus, Dede, 2010, Kedudukan Perjanjian Kerja terhadap PKB dalam hubungan Kerja, Yustisia Edisi 81 September - Desember/2010

Cohen, M.L., and Olson K.C.,1992, Legal Research In A Nutshell. St Paul Minn: West Publishing Co.

Hadjon, P.M.,2015, Perlindungan Hukum Bagi Rakyat di Indonesia, Cetakan ke 5, PT Bina Ilmu,Surabaya.

Husni, L.,2015, Pengantar Hukum Ketenagakerjaan Edisi Revisi, Cetakan ke 13, PT Raja Grafindo Persada,Jakarta.

Kelsen, H.,1967, Pure Theory Of Law. California: University of California Press.

1991, General Theory Of Norms. New York: Clarendon Press.

Marzuki, P.M.,2016, Penelitian Hukum Edisi Revisi, Cetakan ke 12, Prenada Media Group, Jakarta.

Mertokusumo, S., 2009, Penemuan Hukum (Suatu Pengantar), Cetakan ke 6, Liberty, Yogyakarta.

Rawls, J.,1971, A Theory of Justice. Cambridge Massachusetts: The Belknap Press of Havard University Press.

Rifai, A.,2010, Penemuan Hukum Oleh Hakim Dalam Perspektif Hukum Progresif, Sinar Grafika,Jakarta. 
Situmorang, R.L., 2013, Tinjauan Yuridis Tentang Perjanjian Kerja Bersama ditinjau dari Undang-Undang Nomor 13 Tahun 2003, Lex Privatum 1 (1).

Santoso, B.,2012, Hukum Ketenagakerjaan Perjanjian Kerja Bersama, Teori Cara Pembuatan dan Kasus, Cetakan ke 1. UB Press, Malang.

Soekanto, S.,2015, Pengantar Penelitian Hukum, Cetakan ke 15, UI Press, Jakarta.

Soekanto, S., and Mamudji,Sri,2015, Cetakan ke 15, Penelitian Hukum Normatif Suatu Tinjauan Singkat, PT Raja Grafindo Persada,Jakarta.

Soepomo, Imam.,2016, Hukum Perburuhan Bidang Hubungan Kerja, Cetakan ke 7, Djambatan,Jakarta.

Tanya, B.L., Simanjuntak, Yoan., and Hage, Markus Y.,2013, Teori Hukum: Strategi Tertib Manusia Lintas Ruang dan Generasi, Cetakan ke 4, Genta Publishing, Yogyakarta.

\section{Peraturan Perundang-Undangan:}

Undang-Undang Dasar Negara Republik Indonesia 1945.

KUH Perdata (Burgerlijk wetboek)

Undang-Undang Nomor 21 Tahun 2000 tentang Serikat Pekerja/Serikat Buruh (Lembaran Negara Republik Indonesia Tahun 2000 Nomor 131, Tambahan Lembaran Negara Republik Indonesia Nomor 3989).

Undang-Undang Nomor 13 Tahun 2003 (Lembaran Negara Republik Indonesia Tahun 2003 Nomor 39, Tambahan Lembaran Negara Republik Indonesia Nomor 4279).

Umbas, R.R. (2014). Aspek hukum dalam PKB antara karyawan dan perusahaan, Jurnal Hukum Bisnis Lex Privatum, II (3).

Undang-Undang Nomor 2 Tahun 2004 tentang Penyelesaian Perselisihan Hubungan Industrial (Lembaran Negara Republik Indonesia Tahun 2004 Nomor 6, Tambahan Lembaran Negara Republik Indonesia Nomor 4356). 
Undang-Undang Nomor 12 Tahun 2011 tentang Pembentukan Peraturan

Perundang-undangan (Lembaran Negara Republik Indonesia Tahun 2011 Nomor 82).

Warasih, E., (2010). Pranata Hukum Sebuah Telaah Sosiologi. Semarang: PT Suryadaru Utama.

Peraturan Menteri Ketenagakerjaan Republik Indonesia Nomor 28 Tahun 2014 tentang Tata Cara Pembuatan dan Pengesahan Peraturan Perusahaan serta Pembuatan dan Pendaftaran PKB 